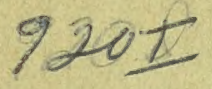

\title{
THE LIFE AND SERVICES
} $-\mathrm{OF}-$

\section{JOHN JAMES AUDUBON.}

\section{AN ADDRESS}

DELIVERED BEFORE THE

\section{MAR 261894} SinA 201894

THE NEW YORK ACADEMY OF SCHETCES,

\author{
APRIL 26, 1893,
}

BY DANIEL G. ELLIOT, F.R.S.E. 







\title{
The Life and Services of John James Audubon.
}

\author{
BY DANIEL G. ELLIOT, F. R, S. E.
}

Mr. President, Ladies and Genthemen-Should we desire to seek for the beginnings of Ornithology, we must look for them in the period when our old earth was yet young; when that strange creature, more bird than reptile, more reptile than bird, according to the impressions received by those who have studied its remains in the slab of Solenhofen, the Archaeopteryx, winged its feeble flight above the landscape of the Jurrassic Age. Evolved from its wholly reptilian ancestors, this, so far as we know, was the first ereature provided with wings composed of feathers to bear it onward and upward in the atmosphere.

There were no artists upon the earth in those days to trans. mit to us the portraits of animals then living, but nature has carefully wrapped this creature in the stone to remain forever an object of our wonder and our admiration.

Unknown ages rolled along, and man appeared upon the scene, but in the evidences of their existence that the pre-historic races have left behind them, no incised stone, or bone, or ivory, contains any representation of birds.

It is only when we reach what may be deemed modern times, in comparison to the periods of which I have referred, that we meet with colored pictures of birds, and although it is now more than three thousand years since the artist painted their por- 
traits, yet the fresco of six geese, taken from a tomb at Maydoom, in Egypt, and now deposited in the museum at Boolak, is so fresh, and depicted with such marvelous fidelity of form and coloring, that four of these figures, can without hesitation be referred to two species living in the old World to-day, one of which, the white fronted goose, has a very near relative in our own land, and known to many as the Brant of our Western prairies. There were probably most excellent and learned naturalists among that wonderful people living on the banks of the old Nile, but their names have been lost in the overthrow of their nation, and it was not until the fourth century before Christ that the first serious ornithological author appeared in the person of Aristotle. He was followed in the first century of our era by Pliny the Elder, and then we come to the sixteenth century before we find a name at all familiar to us. The seventeenth and eighteenth centuries produced a host of naturalists, some preëminent in ornithology; and it was towards the close of this century that he appeared upon the scene, in honor of whose memory we are assembled here this evening.

In the resurrection period, the most beantiful season of the year, when all the groves were echoing with melody issuing from countless feathered throats, singing a natal song to him who was to be ever the birds' lover and friend, and the air was redolent with the fragrant breath of opening buds and flowers, on the 4th May, 1780, in the then French province, now the State of Louisiana, on his father's plantation, John James Audubon was born. His mother's maiden name was Anne Moynette. She was a lady of Spanish extraction, possessed both of wealth and beauty. A few years after the birth of her youngest son Mrs. Audubon accompanied her husband to St. Domingo, and there perished during an insurrection of the negroes. The elder Audubon then returned to France with his family, and the future naturalist was sent to school, and was instructed in mathematics, geography, drawing, music and fencing, and in the last three he became proficient. He played well upon the violin, flageolet and guitar, and was a graceful dancer, an accomplishment that in after years he was to have more opportunities of practicing with bears and other wild denizens of the forest than with the fairer sex of his own species. During his school days, at every opportunity that offered, young Audubon would wander away to the woods and fields to collect objects of natural history, and he also made about two hundred drawings of the birds he procured. Declining to join the armies of $\mathrm{Na}$ poleon, his father sent him to America to look after some property called Mill Grove, which he had purchased on Perkiomen Creek, near Philadelphia. 
Here he led an ideal existence from his view of life. He had ample means, was gay and fond of dress and all his time was occupied in hunting, fishing and drawing, and he was without any care. His own description of himself, given at this time, illustrates the frank, open, simple character of the man, one which he was never to lose throughout all his career so full of vicissitudes, discouragements and trials. He says: "I had no vices, but was thoughtless, pensive, loving; fond of shooting, fishing and riding, and had a passion for raising all sorts of fowls, which sources of interest and amusement occupied all my time. It was one of my fancies to be ridiculously fond of dress, to hunt in black satin breeches, wear pumps when shooting, and dress in the finest ruffled shirts I could obtain in France." What a contrast to the backwoodsman of the years to come, wandering over little known portions of the land, clad in plainest garments, often all the worse for wear, totally unmindful of his personal appearance, intent only upon the discovery of some new species, or the capture of one already known, but not yet added to his collection. His mode of life at this time was as abstemious as his dress was extravagant. He ate no meat, lived chiefly on fruits, vegetables and fish, and never drank a glass of spirits or wine until his wedding day. To this he attributed his continual good health, endurance and iron constitution. When, in after years, he looked back upon this happy period of his youth, he exclaims: "And why, have I often thought, should I not have kept to this delicious mode of living:" But it was not to be; he had his special part in life to play. He was to be no idle dreamer, no beruffled dandy, fritting away his days in fruitless pastimes, but even as he was penning the description of himself at Mill Grove, the day was dawning that should usher to him a new existence, one of happiness, indeed, yet full of trials, suffering, discouragments, of long-continued struggles against adversity, often of penury, and of manifold disappointments, to be finished at last with a complete success, an immortal name and an everlasting peace.

And the chief cause for all this change in his life was nigh at hand. It is the old, old story. Within sight of his house, at Flatland Ford, lived William Blakewell and his family. He was an English gentleman, a descendant of the Peverills, rendered famous by Sir Walter Scott in his novel of "Peveril of the Peak." Descending from the Norman Count Basquelle, the name had been corrupted into Baskiel, and then Blakewell. Audubon raised in the Napoleonic atmosphere which made everything English abhorrent to a Frenchman was so uncivil as to delay for a long time to return the visit his neighbor had 
paid him. But it was of no avail to struggle against his fate, and one morning he entered the Blakewell residence. He was shown into a drawing-room, when a young lady rose to welcome him and to assure him of the pleasure her father would have in receiving him. This was his introduction to Miss Lucy Blakewell, his future wife, who proved to be a most fitting mate for such a man as Audubon. Affectionate, patient, sympa- thetic, entering with her whole lieart into her husband's pursuits, self-sacrificing, ever ready to encourage him when depressed by disappointments, jealous of his reputation, cheerfully submitting to any privation in order that his immortal work should be carried to a successful completion, enduring without a murmur long separations from husband and children, and accepting at times the ancongenial labor of teaching to gain means to advance the publication of his book; she was a type of that woman of whom it is written, "her children shall rise up and call her blesssed," and whatever wreath shall be twined for the brows of the naturalist, sprays from it must be taken to form a similar crown to adorn the head of his faithful, devoted wife.

The acquaintance thus formed ripened into intimacy, and in due course of time on expressing to $\mathrm{Mr}$. Blakewell his desire to unite himself with his daughter, he was advised before marriage to gain some knowledge of mercantile pursuits, which, with his characteristic impulsiveness, Audubon at once put into practice by going to New York, entering the counting house of Mr. Benjamin Blakewell, and beginning his acquaintance with business methods by losing several thousand dollars in speculation. It was not long before Mr. Blakewell discovered that it was impossible to make a merchant of Audubon, and he returned to Mill Grove. During all this time he kept adding to his collections. visiting constantly the woods and fields, and his rooms were turned into a museum filled with all manner of specimens in Natural History. He has given a sketch of himself at this time, which brings him vividly before us. "I measured," he writes, "five feet ten and a half inches, was of a fair mien, and quite a handsome figure, large dark and rather sunken eyes, light colored eye-brows, aquiline nose, and a fine set of teeth; hair, fine texture and luxuriant, divided and passing down behind each ear in luxuriant ringlets as far as the shoulders,"

After his return to Mill Grove, he decided to go to Louisville, Kentucky, and having sold his place he invested the proceeds in goods, and was married to Miss Blakewell on the 8th of April, 1808 .

It was while residing at Louisville a memorable occurrence 
took place. One morning a man with two rolumes under his arm entered his counting room. Audubon describes him as having a long, rather hooked nose, keen eyes and prominent cheek-bones, stamping his countenance with a peculiar character. He was dressed in a short coat, waistcoat and trousers, of grey cloth. This man was Alexander Wilson, the pioneer in the field Audubon was destined to enter, the Father of American Ornithology. He walked up to the table at which Audubon was working, opened his books, explained his occupation, and requested his subscription, thus illustrating in a measure the method which in after years Audubon himself was obliged to adopt in order to bring his own work before the world and accomplish its publication. Surprised and pleased at the sight of the plates, Audubon took his pen to write his name among those of the subscribers, when his partner said to him in French, "My dear Andubon what induces you to subscribe to this work; You drawings are certainly far better, and again you must know as much of the habits of American birds as this gentleman." "Vanity and the ecomiums of my friend prevented me from subscribing," is his frank, though sad statement. Wilson probably understood French, for he asker Audubon if he had many drawings of birds. 'Taking down a large portfolio, its contents were exhibited much to the surprise of Wilson, who said he had no idea that anyone besides himself was engaged in making such a collection, but was still more astonished when asking if it was Audubon's intentions to publish, he was answered in the negative. They met but once again during one of Audubon's visits to Philadelphia, when he called on Wilson and found him engaged in drawing the white headed Eagle. Audubon says he was received with civility and taken to the exhibition rooms of Rembrandt Peale, but they spoke not of birds, and shortly afterwarls the two men whose names are more closely interworen with American ornithology than any others ever can be, and whose tastes and pursuits should have proved the magnet to draw them most closely together, parted never to meet again. 'The melancholy reserve of the quiet, shrinking Scotchman could not be conquered even by the vivacity of the enthusiastic Franco-American, and their brief acquaintance brought no profit to either. Business at Louisville did not prosper, and Audubon sold his interest to his partners and went to Henderson. While traversing the country between these places, and also during his residence in them, most of his time was given to roaming the woods, hunting with the Indians, studying wild animals and drawing their portraits. He now entered into a partnership with his brother-in-law,under the firm 
name of Anclubon \& Co., to carry on business in New Orleans, and embarked in this enterprise all his fortune. But as usual, instead of attending to business, he passed his days hunting and fishing, and was soon informed that all his means had been lost.

He was now nearly at the end of his resources, but gathering

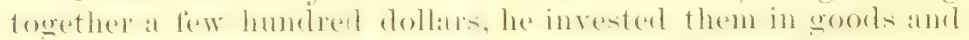

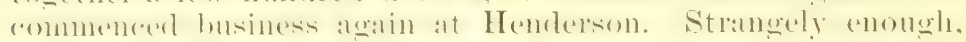

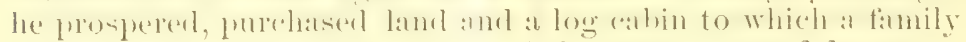
of negroes was attached as part of the property, and began to be pretty comfortable.

'This state of affairs. howerer" was not lone to continue, for he was soon joined by a former partner, whose alliance always brought disaster, and who now persuaded him to erect a steam mill, which brought all interested in it to ruin. II troubles increased daily, and he was assailed by all mamer of difliculties. Giving up to his creditors all he possessed, he departed with his family, dog, gun and precious drawings, from which he never allowed himself to be separated, and went to Lonisville, and then to Cincinnati, where he was engaged as a kind of curator in the museum, his work being chiefly that of a taxidermist.

From Cincinnati he went to Natchez and was engaged to teach drawing in the college at Washington, near that town. His work intertererl greatly with him ornithological pursulis and depressed his spirits, and although he prospered he says, "the hope of completing my book upon the Birds of America [which he now desired to publish] became less elear, and, full of despair, I feared my hopes of becoming known to Europe as a maturalist were destined to be blasted." "Throughout his writings there is found these constant expressions of this desire to become known and to leave a name upon the roll of naturalists, but it was not a representation of " Fame blowing out from her

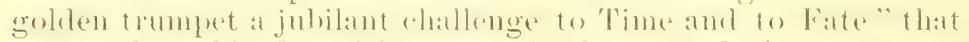
appeared to his despairing eyes, for he seemed always to perceire a ythiescent gouldess with trumpet idle in her hame, and to hear no resonant note blown in recognition of himself, and in frank and simple language he expressed his fears that he should die unheralded and unknown.

Mrs. Audubon wished her husband to go to Enrope to receive instruction in oil painting, and to aid him in accomplishing this. engaged herself as goveruess in a family at Bayou Sara. Audubon having exhausted his patronage at Natchez resolved to start with an artist named Stein in a wagon and make a trip through the Southwestern States as perambulating portrait painters,

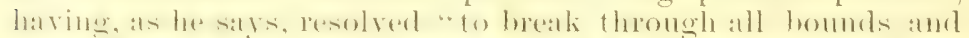
follow his ornithological pursuls." His friends reagaled him 
as crazy, his wife and family alone gave him encouragement. His wife, he writes, "determined that my genius should prevail, and that my final suceess ats an ornithologist should be triumphant." Always his wife,-wherever throughout his career, we learn of trouble, disappointments, vexation of all kinds, and monetary difliculties innumerable overtaking him, it is always his wife who encourages the despationg heart. strenerthens the wealening faith and points him onwarl to the distant goal, which her woman's trust in his abilities shall surely help him to obtain.

His trip with Stein was a failure financially, and returning to Natchez he went to Philadelphia. There he met the artist Sully, who gave him valuable lessons in oil painting, and he worked hard to complete his drawings of birds. His friends and the engravers of Wilson's plates all recommended him to visit Europe, and he decided to follow their advice, and left Philadelphia to return to Bayou Sara. In New York he was introduced by Dr. DeKiay to the members of the Lyceum of Natural History, now the Academy of Sciences, which has been instrumental in raising the monument this day unveiled, and moler whose anspices we mest this evening. IIis drawings were exhibited to the members, "among whom," he sars, "I felt awkward and uncomfortable. After living anong such people I feel clonded and depressed; remember I have done nothing, and fear I may die unknown. I feel I am strange to all but the birds of America. In a few days I shall be in the woods and quite forgotten."

On arriving at Bayou Sara he began to consider what he could do to hasten the publication of his drawings. His wife was receiring a large income for those days, nearly $\$ 3,000$, which she offeres to grive him, and he resolved on an effort to increase the amount. From Woolville came a special invitation to teach dancing, and a class of sixty pupils was formed. "The dancing speculation," he says, "fetched $\$ 2,000$, and with this capital and my wife's savings I was now able to foresee a successful issue to my great ornithological work."

On 26th April, 1826, he sailed from New Orleans for Liverpool in the ship Delos. provided with numerous letters of introduction, and reached his destination on the 20th July. In Edinburgh he met Mr. Lizars, the engraver of Selby's great work on British Birds, who offered to bring out the first number of the Birds of America, and on the 28th Fovember he was presented with a proof of the first plate.

He was well received here, and on December 10th writes: 
"Mr suceess in Edinburgh borders on the miraculous. I am féted, feasted, elected honorary member of societies, making money hy my exhibition and my paintings. It is Mr. Audubon here, and Mr. A udubon there, and I can only hope that Mr. Audubon will not be made a conceited fool at last."

He continued to rear his hair long and flowing on his shoulders, which made him very conspicuous wherever he went; and once a stranger suggested to him to paint an Osage Indian hunting wild turkeys, as likely to prove an attraction. On which he comments: "Xo doult it would, for whatever is most strange is most taking now. But so long as my hair floats over my shoulders I shall probably attract attention enough, and if it hung to my heels it would attruet more."

He was elected a Fellow of the Roral Societr, and commentincr on it in a letter to his wife, he says: "So, joor Audubon, if" not rich, thou wilt he honored at least and held in esteem among men.

He now issued his Prospectus for the Birds of America, arranged his aftuirs, and under the importunities of his friends, cut ofl his hair which he had so long worn in ringlets, and started for London. Here he worked rery hard and painted many pictures, a number of which. by the help of Sir 'Thomas Lawrence, he was able to dispose of at rarious prices from \pm 10 to $£ 30$. Withont the sale of them he was, as he says, bankrupt when his work was scarcely begun, and all his hopes blasted, for he had actually to borrow five pounds to purchase materials for his pictures. When he had completed une of these, he would go out in the evening and risit the shops of the Jews and others, and take any price he could get for it. In this way he sold : large number, and when in after years he sought to find these pictures he was unable to trace a single one.

Up to this time there was no text to his book, the plates alone having been issued without any accompanying explanation. He now commenced to prepare the Ornithological Biography, which eventually filled fire rolumes. He felt himself unfitted for this literary work, and applied to Mr. James Wilson of Edinburgh to recommend some one who, to use his own words, "would undertake to correct my ungrammatical manuscript, and assist me in aranging the more scientific part of the Biography of Birds." and was referred to Mr. William MeGillivray. No better or more fortumate choice could have been made, and whatever scientific value there is in Audubon's biography is derived largely from MeGillivray's coöperation. Audubon worked incessantly at this book, McGillivray keeping abreast of him, and Mrs. Audubon re-wrote the entire manuscript to send to America and secure the copyright there. 
In three months the first volume was finished and offered to some publishers, none of whom would give a shilling for it, and the author issued it himself. In his search for subseriber's he relates his experience with Baron Rothschild. He called at the banking house, and soon the Baxon entered and, he says, " dropped his fat body into a comfortable chatr as it "aring for no one in the world bit himself." Audubon presented his letter of introduction and was met with the question, "Pray, sir, is this a letter of business, or is it a mere letter of introduction?" As he had not read it, Audubon could not say; the Baron opened it, glanced at the contents and said, "This is only a letter of introduction, and I expect from its contents you are the publisher of some work or other, and need my subscription." "Had a man the size of a mountain," says Audubon, "spoken to me in that arrogant style in America, I shonld have indignintly resented it. hut where I then wats it sermenl hest to swallow and digest it as best I could." The Baron then said, "I nerer sign my name to any subseription list, but you may send

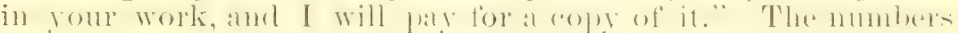
were regularly delivered, and in abont a year's time Victor

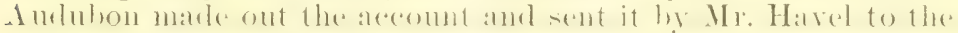
banking house. 'The Baron lookerl at it with amazement: "What! a hundred pounds for birds! Why, sir, I will give you five pounds and not a farthing more." Explanations were unavaling, and the work was actually returned to Mr. Havel's shop from the Baron's residence, and Audubon remarks, "I kept the work, and sold it afterwards to a man with less moner, but a nobler heart."

Leaving his wife and son in London, Audubon again visited Ameriea, and went to 'lexas, where he passed most of the winter in search of material for his work, and in May returned to England, and in the autumn of 1839 the Birds of America, the most magnificent ornithological work the world has ever seen, and the Ornithological Biography being both finished, he came back to America and settled in New York, not, howerer. to be idle, that was impossible for a nature like Audubon's, lnt le immerlintely lewan an erlition of his large work in tho size. This was completed in seven volumes in 1843.

In the spring of this year he started on his last expedition, to visit the Yellowstone river, and procure material for a work on the Quadrupeds of North Ameriea, and he went as far as Fort Union on the Missouri, at that time an ontpost on the borders of civilization. 'I'wo years afterwards appeared the first volume of this great work, the other two were prepared mo-tly he his sons, Victor and John, the last one appearing the year $A$ udubon 
died. In this work the naturalist associated with himself as coauthor, the Rev. Dr. John Bachman, of Charleston, South Carolina, who is responsible for the scientific portion, and, like McGillivray in the Birds of America, proved to be of the greatest possible assistance in the construction of the text, and scientific arrangement.

In this hasty sketch of the naturalist's life, I have touched mon some of the most important or interesting inciclents of his career, exhibiting in various lights the impulsive, mercurial disposition of the man, which urged him often to enter upon impracticable and unwise undertakings, and yet permitted him never to remain steadfast in the pursuit of material advantages, even thongh the necessity for close application to gain them was paramount. He was born to accomplish a certain task, and no matter what the condition of his life may have been, nothing could divert his mind from the subject with which his whole nature was imbued, nor any privation discourage him from following the pursuit and study of his beloved birds.

He was a woodsman, not a scientific naturalist, according to the ideas prevalent to-day. He loved to go into the forests and wateh the (reatures that ifwelt among the leafy lanes and thickets; to study the birds in their time of love-making, nesting and migration, and to draw their forms upon the canvas. But of books he was no student; of the intricate scientific details of his mighty subject he was unconcemed and indifferent; sufficient for him it was, to learn where and how his feathered friends lived and moved, and to produce their portraits.

He was possessed of a most indomitable resolution and perseverance in following his life work. It is almost sublime the courage he displayed, and the indifference to those things which are generally first considered by his fellow-men, as exemplified by him at the commencement of the publication of the Birds of America. He was on the verge of failure, with but one sovereign in his pocket, and knew not a single individual from whom he could borrow another, and yet he extracted himself from his difticulties by rising at four in the morning, working hard all day, and disposing of his pictures, "at a price that a common laborer would have thought little more than a sufficient remmeration for his work." And yet, during the publication of his first volume, abont forty thousand dollars passed throngh his hands. While the book was in progress, no less than fifty subseribers abandoned him, representing a total sum of fifty-six thomsand dollars and to replatee them he was obliged to tramp through the provinees in quest of others.

From his French extraction he inherited the impulsive char- 
ncter of the race, which at times influenced his judgment, and led him into wild and umprofitable pursuits. But his many severe and oft recurring pecuniary embarrassments in time sobered him, and in his maturer years he exhibited little of the fanciful vagaries of his earlier life. As an artist, and a pupil of David, we must judge him, and the master's influence is frequently seen in the composition of his plates. While the grouping is well considered and the fignres spirited, they often partake of the theatrical in their attitudes and occasionally are anatomically impossible. Yet the eflect is almost always pleasing and apt to evoke almiration.

As a naturalist, we must not judge him by the standard of to-day, achieved in the severe and exacting curriculum of modern scientific teaching. The ornithologist of the close of the nineteenth century is altogether another savant from the one Audubon understood by the term, nor does he quite answer to the description I once heard given by a lady, as one who was "always fussing over little fluffy birds." He must not only know the habits and economy of birls as Audubon did, but also very much more. And first, he must be thoroughly versed in the bibliography of his subject, a mighty task, in which few are thoroughly profieient; he must be conversant with at least fire languages, French, English, German, Italian and Latin, for in all of these and more, are the memoirs of his science published throughout the world. He must be accuanted with anatomy and osteology to understand not only the comparative relationship of the animals, comprised in the orders and families of his own especial branch, but also their aflinity to those in other departments of zoülogy; he must understand pterylography, the growth and structure of feather's, and the distribution of feather tracts, and be able to see the significance of these, and what they imply; he must be skilled in the theory and facts of geographical distribution, and be able to give a probable reason for the cause of the various habitats and dispersion of the animals on our glohe; he must have knowledge of geology and paleontologr, so as to be ahle to sturly intelligently the fossil remains of extinct forms, and read aright the lessons that they teach; in fact, because the rarious sciences are so intimately connected, to be fully equipped for his work, he must be not only an ornithologist, but also a zoülogist and if possible a biologist as well.

It is no small thing to be a graduate in such a school, and few, indeed, are they who by their works have proved themselves fitted to take a place in the front rank of the science. One must begin early in life, work hard all the time, passing 
gradually from one degree of proficiency to another (for ornithology is a science with ever-opening vistas of continued possibilities of progress) until, after a life passed in diligent and honest labor, so brief is our allotted time here, that one finds himself only upon the threshold of his subject, with vast sonrces of knowledge lying just beyond. Such, in brief, is the ornithologist of to-day, an expert in no mean branch of scientific pursuit, and yet mindful of what is required to constitute such a sarant, so little is the science appreciated and its acquirements understood, it is sad, indeed, to know that even in this late day there are those who believe that a man requires little or 110 training to become a naturalist, and that almost any one is competent to give instruction in the mysteries of zoölogy.

The ornithologist is not made, but born to fill his role in life as is the poet and as you cammot construct a maturalist, neither an you hestroy that indesistihle impulse which compels him to follow his allotted part, and which was implanted into his rery nature by the Great Ruler of Events with the first breath he drew.

You may instal him in places of profit, and where material adrancement is certain, and though he may honestly do all he can while so situated, it is not the best he ean do, for his abilities have not their legitimate scope and his eftorts are hampered by uncongenial surroundings. Like Audubon, it is rare that a man possessed with talents which enable him to succeed in any branch of natural science, even though it be of one apparently the least important, can command success in any business pursuit. 'The heart is not in it; mwise and foolish as it may seem to the rast majority of mankind, material gain, such as wealth for itself' alone, and the vain fictitions rank it gives to its possessor, presents no attractions to the man of science. To work to gather up money for itself allures him not; his heart and soul is with higher things, to seek and learn the truth, to strive and find out how God works, to study the creatures that, like himself, owe their existence to the Divine First Cause, and have been, through countless ages, progressing ever onward and upward from a lower to a higher degree of physical and mental attainments.

As in the youthful age of the old earth the ungainly reptile, with its leathery skin and tooth-armed jaws, keeping down from undue expansion the equally unattractive creatures which formed its prey, has gradually through multifold evolutions during the changing ages been transformed into the graceful,

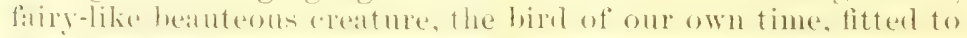
fill a higher destiny in a more perfect world, so has the natural- 
ist advanced with his subject,- from the first debased creature, seemingly unworthy of the name of Man, with eager eyes watching the animals about him, ald haterl solely with the desire for food, until, haring kept step and time with the march of the

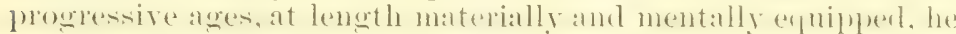
is able with the eye of fith and finger of instinct to perceive and point out the ways and methorls of Creative Power. For the entire universe is ever moving onward and upward; there is no cessation in the march of development; advance! "Go forward!" is and has ever been the divine command. To hesitate, to pause, means death, and there can be no retrogression. Type breeding only unto type ends surely in annihilation. To stand still is to cease to exist, to go ever forward from one height to another still higher in the only method for al continuer life. Such is the manifest law of Omnipotence, and only that which is capable of a higher development can survive.

Man-that highest of earthly types-is no exception to this law, but in himself exemplifies its truth and force in the evidences of his own existence. The races incapable of farther advancement become extinct, only those survive which contain within themselves the seeds of continued progress, and which, on looking on their history, can say,

"I have climbed the snows of Age, and I gazed at a field in the Past. Where I sank with the body at times, in the sloughs of a low desire,

But I hear no yelp of the beast, and the Man is quiet at last,

As he stands on the height of his life, with a glimpse of a height that is higher,"

We may not, thelefore, as I have already said, judge dudubon by the standard of to-day, any more than we ourselves shall be measured by that employed by maturalists half a century hence. He was an ornithological artist, not a scientific naturalist, and no one appreciated this fact, and was more ready to acknowledge it than the simple, frank and enthusiastic anthor of the Birds of America. He never made pretence to be more than he really was; he never claimed to anything higher than to be a lover of animals, their faithful illustrator, and the historian of their lives, but in this role he occupies a formost place, and has gained an imperishable name. We must consider him as he struggled and worked in the dawn of the scientific period, in the blaze of whose noonday sun we ourselves live.

He is most remarkable for his energy and indomitable perseverance in battling against the difliculties presented in the exploration of a little known, wild and for the most part uncivilized land, permitting few opportmities, even if' he had the 
desire, for the study and careful investigation of that scientific portion of his subject, of which he frankly declared himself to have been ignorant.

But we admire in him the painstaking observer, the field naturalist, who, daunted by no difticulties, penetrated the unknown forests, living with the Indians, or in the midst of scarcely less salvage heasts, enconntering with chereful courage momminered privations. humerer, cold, stoms amel oppressive heat, to secure specimens which afterwards were made to live again in the pages of his immortal work.

He was the type of that class of naturalists whose labors provide the means by which his more scientific brothers are enabled to reach definite conclusions, demonstrate Nature's problems and explain the laws by which her kingdom is governed.

There is not now left much for me to tell. Audubon returned from his last expedition in Oetober, 18t3, and immediately began to work upon his Quadrupeds of America, the first volume of which appeared two years afterwards. He lived on his place, now known as Audubon Park, at that time far removed from the byicks, dust and grime of the great city, which he could never tolerate. "Ah," he once said, "how often when I have been abroad on the mountains, has my heart risen in grateful praise to God, that it was not my destiny to waste and pine among the noisome congregations of the city."

The first volume of the Quadrupeds was his last work. He retained his simple habits, passed much of his time in the woods or at his ensel; but he was now verging towards three score and ten, and while the love of his pursuit was as great as ever, the mumber of his accomplisherl rears hat tempered the ardor of his energetic spirit, and the fire of his youthful passion was gradually lapsing into a fitful glow.

His life was peaceful and happy, surrounded, as he writes "by all the members of my dear family, enjoying the affection of numerous friends, who have never abandoned me, and possessing a sufficient share of all that contributes to make life agreeable. I lift my grateful eyes towarls the supreme Being and feel that I am happy."

One day he discovered that he could not adjust his glasses so as to find a focus upon his canvas, and from that moment he began to fail. The devoted wife, who had always been his mainstal throughout his cheyuered career, now never left him, realing to him, and during his walk alont the grounds that surrounded the house and which stretched to the banks of the Hudson, was always at his side. But the once erect, lithe and agile figure was now lost in the feeble form of a weak old man. 
"Waning life and weary,

Fainting heart and limb,

Darkening road and dreary, Flashing eye grown dim,

All betokening nightfall near,

Day is done and rest is dear.'

'T'owards the last another' shadow fell upon him and his mind failed, and his eye, noted for its brightness, became dim, and during the remainder of his stay on earth like a little child he was led by the hand.

On the 27th of January, 1851, the summons came, and as he by upon his bed, surromeded hy his fanily, his eyes regaimed their lustre, as though they benetriterl the reil and lookerl heryond the river into that land that is "very far off", and with his hands clasped in those of his wife he passed peacefully away.

He sleeps by the side of our noble river, which in its fair and full proportions with stately sweel mores calmly onwarl to it s own rest in the bosom of the great deep, so nigh at hand, while above him, bearing upon its chiseled sides reproductions from his own drawings, rises the splendid monument this day unveiled in honor of his memory and to commemolate his work.

His labors accomplished, his vocation fulfilled, how can I more fittingly express it all than by those lines so full of music, which tell of a life well lived from its rising to its setting sun; of the contemplation of a peaceful passing hence that no alarms can stir, and of the possession of a steadfist unfaltering trust when standing on the borders and looking out upon the glassy surface of the vast, mnknown eternal sea?

"Sunset and evening star,

And one clear call for me,

And may there be no moaning of the bar

When I put out to sea,

But such a tide as moving seems asleep,

Too full for sound or foam,

When that which drew from out the boundless deep

Turns again home.

Twilight and evening bell

And after that the dark,

And may there be no sadness of farewell

When I embark.

For the' from out our bourne of 'Time and Place

The flood may bear me far,

I hope to see my Pilot face to face

When I have crossed the bar." 





Gaylord PAMPHLET BINDER Syracuse, N. Y. Stockton, Calif. 
SMITHSONIAN INSTITUTION LIBRARIES

39088013487541 